Int. J. Dev. Biol. 51: 45-56 (2007)

doi: $10.1387 /$ ijdb.062152js

Original Article

\title{
Induction of reverse development in two marine Hydrozoans
}

\author{
JÜRGEN SCHMICH ${ }^{*}, 1$, YULIA KRAUS ${ }^{2}$, DORIS DE VITO ${ }^{1}$, DARIA GRAZIUSSI ${ }^{1}$, FERDINANDO BOERO ${ }^{1}$ \\ and STEFANO PIRAINO*,1 \\ ${ }^{1}$ Dipartimento di Scienze e Tecnologie Biologiche ed Ambientali, Università di Lecce, Italy and \\ ${ }^{2}$ Department of Evolutionary Biology, Biological Faculty, Lomonosov Moscow State University, Russia
}

\begin{abstract}
Cnidarians are unique organisms in the animal kingdom because of their unequalled potential to undergo reverse development (RD). The life cycle of some species can temporarily shift ordinary, downstream development from zygote to adult into the opposite ontogenetic direction by back-transformation of some life stages. The potential for RD in cnidarians offers the possibility to investigate how integrative signalling networks operate to control directionality of ontogeny (reverse vs. normal development). Striking examples are found in some hydrozoans, where RD of medusa bud or liberated medusa stages leads to rejuvenation of the post-larval polyp stage. Artificial stress may determine ontogeny reversal. We describe here the results of experimental assays on artificial induction of RD by different chemical and physical inducers on two marine hydrozoans, Turritopsis dohrnii and Hydractinia carnea, showing a different potential for RD. A cascade of morphogenetic events occurs during RD by molecular mechanisms and cellular patterns recalling larval metamorphosis. For the first time, we show here that exposure to cesium chloride (CsCl), an inducer of larval metamorphosis, may also induce RD, highlighting similarities and differences between these two master ontogenetic processes in cnidarians.
\end{abstract}

KEY WORDS: Cnidaria, reverse development, CsCl, heat shock, chemical induction, metamorphosis

\section{Introduction}

The basic life cycle of cnidarians is usually represented by a one-way alternation of sessile and motile phases. In Anthozoa sexual reproduction of adult polyps generate crawling or swimming planula larvae, which will metamorphose into new polyps. In Medusozoa the polyp itself becomes a post-larval stage preceding the sexual stage, the pelagic medusa. Many variations to this scheme are possible (Boero et al., 2002 for a review). Among them, reverse development (RD) was first discovered in scyphozoans nearly a century ago (Hadzi, 1909) and it represents an unparalleled feature of cnidarians within the animal kingdom (Piraino et al., 2004) (Fig. 1). In several representatives of both Anthozoa and Medusozoa, one stage in the life cycle can transform back - by morphological reorganization - to the preceding stage: e.g., a medusa or medusa bud reverting back into stolons and polyps, an ephyra back into a scyphistoma, a primary polyp back into a planktonic larva (see Piraino et al., 2004 for review of $\mathrm{RD}$ cases). This phenomenon can be interpreted as an adaptive response to unfavourable changes in the environmental quality or to physiological feedbacks: in the hydrozoan Turritopsis dohrnil (not T. nutricula, see Schuchert, 2004) RD (medusae to polyps) is activated either by epigenetic, sub-lethal stress (e.g. starvation, temperature or salinity changes) or by an endogenous, genetically programmed induction when sexual maturity, marking the beginning of senescence, is attained (Bavestrello et al., 1992; Piraino et al., 1996, Piraino et al., 2004). Formerly considered as an extraordinary feature limited to a few species, the RD potential has been recently discovered in other cnidarian taxa (e.g., De Vito et al., 2006), suggesting that it might be a more general property than previously thought.

Hydrozoans exhibit a striking developmental plasticity (Boero, 1984; Gili and Hughes, 1995), including RD of adult stages. Several hydrozoan species show the potency to revert their ontogenetic programs (see Piraino et al., 2004 for a list) but most of them have some restrictions. For instance, the potential for RD of medusa bud to the polyp stage is known in H. carneaup to early isolated stages and is lost in older medusa stages (Müller, 1913, Frey, 1968, Schmid, 1972) (Fig. 1). Two distinct times can be identified throughout medusa bud development, when RD potential drastically changes:

a) Time of autonomous medusa bud development (autonomy point). Before this point in ontogeny, all isolated medusa buds

Abbreviations used in this paper: $\mathrm{ND}$, normal development; $\mathrm{RD}$, reverse development.

\footnotetext{
*Address correspondence to: Prof. Dr. Stefano Piraino or Dr. Jürgen Schmich. Di.S.Te.B.A. Università di Lecce, via per Monteroni, 73100 Lecce, Italy. Fax+39-0832-298616. e-mail: stefano.piraino@unile.it or jschmich@web.de
} 
reverse to the polyp stage. Creeping stolons are always reformed, some lead also to hydranth reformation. This indicates that at early stages of bud development, the contact to the parental polyp is still obligate to form medusa. Beyond this point, medusa development may be independent from the connection to the polyp and the percentage of isolated medusa buds leading to functional medusae (even though smaller in size than the normal ones) is constantly increasing with time.

b) Time of medusa determination (point of irreversibility). Beyond this point, all isolated medusa buds eventually develop into medusae and the possibility of reverse development to polyplike structures is fully inhibited. This last point can shift to older bud stages if the integrity of bud tissues is altered by physical injury (Schmid, 1972). This treatment forces late stages of medusa buds up to stage 8-9 (that normally would develop into medusae) to undergo $\mathrm{RD}$, but usually not overcoming the time when, from stages 8-9 onward, typical medusa structures are stabilized by the swelling of the outer mesoglea (see Achermann, 1978).

Polyp formation during RD in $H$. carnea occurs in low numbers from early isolated medusa buds, which in most cases give rise only to creeping stolons (Schmid, 1979). As for medusa determination, the developmental stage of medusa buds sharply influences the potential for full polyp formation. The experimental destabilisation of the medusa bud structures by mechanical squeezing shifts the point of medusa determination towards older

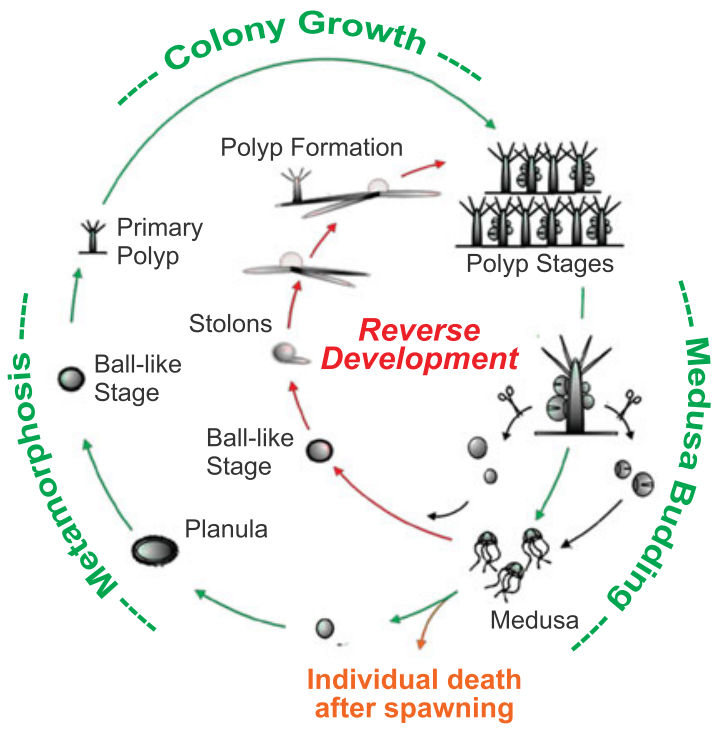

Fig. 1. Life cycle of Turritopsis dohrniiand Hydractinia carnea. During the normal life cycle, polyp colonies bud gonochoric medusae which are eventually liberated into the free water column. After a period of planktonic life, mature medusae release their gametes and, following fertilization, a planula larva is formed in a couple of days. Usually medusae die after the release of the gametes. The mature planula larva undergoes metamorphosis upon an external bacterial signal and forms the primary polyp, the starting unit to form a new polyp colony. T. dohrnii shows an extraordinary variation to this regular life cycle, that is reverse development: the medusae are able to transform back into the polyp stage by asexual processes. H. carnea has a reduced potential to undergo this process, limited to young medusa buds (for details see Introduction).
TABLE 1

\section{STAGES OF REVERSE DEVELOPMENT IN TURRITOPSIS DOHRNII}

\begin{tabular}{|c|c|}
\hline Stage & Description \\
\hline 0 & $\begin{array}{l}\text { Normal medusa, with } 10 \text { tentacles. The canal system starts from the base of manubrium } \\
\text { and is formed by four radial canals and a circular (ring) canal at the umbrellar margin. } \\
\text { Tentacle bulbs and tentacles originate from the ring canal. (Fig. } 2 \text { A). }\end{array}$ \\
\hline 1 & $\begin{array}{l}\text { The manubrium shortens and the ring canal and tentacle bulbs fuse together. Tentacles } \\
\text { reduce and /or contract as little stumps. The radial canals are still unchanged, while } \\
\text { interradial sectors of the bell shrink in a four-lobe clover structure, closed by the } \\
\text { constriction of the ring canal. Adradial parts of subumbrella/umbrella are still visible as } \\
\text { the more extended and outstanding parts (four-lobe clover stage). The size of the } \\
\text { medusa decreases about two times (Fig. } 2 \text { B). }\end{array}$ \\
\hline 2 & $\begin{array}{l}\text { Ring canal, radial canals and manubrium fuse together, but still some parts of the } \\
\text { original structures can be distinguished. The subumbrellar muscle layer detaches from } \\
\text { the umbrella. The former four-lobe clover morph changes into a multi-lobed structure, } \\
\text { due to the destabilization of the radial canals and the mesoglea (Fig. } 2 \text { C). }\end{array}$ \\
\hline 3 & $\begin{array}{l}\text { All former medusa structures are completely reduced or melted together to an oval } \\
\text { longitudinal structure (Fig. } 2 \text { D). }\end{array}$ \\
\hline 4 & $\begin{array}{l}\text { The oval structure has changed into a "ball-like" structure. In this stage the transforming } \\
\text { specimen wraps into a chitinous perisarc and attaches to the substrate (Fig. } 2 \text { E). }\end{array}$ \\
\hline 5 & $\begin{array}{l}\text { Stolon tips, growing out from the ball-like stage, are visible. The number of stolon tips } \\
\text { is variable, from one to several (Fig. } 2 \text { F). }\end{array}$ \\
\hline 6 & Specimens with definite hydrorhizal stolons (Fig. 2 G). \\
\hline 7 & $\begin{array}{l}\text { First polyp bud, the ball-like structure progressively becomes empty and can be } \\
\text { distinguished by the perisarc only, since all cells are transforming into stolon tissue (Fig. } \\
2 \mathrm{H}, \mathrm{I} \text {. }\end{array}$ \\
\hline 8 & Growing polyp, tentacle buds are visible (Fig. 2 I). \\
\hline 9 & Functional polyp: a new colony will soon arise (Fig. 2 J). \\
\hline
\end{tabular}

medusa bud stages and thereby increases the possibility to give rise to complete polyp structures.

The potential for RD in cnidarians offers the possibility to investigate how integrative signalling networks operate to control directionality of ontogeny (reverse vs. regular development). On this aspect, many points of the process are still unclear. The present study provides new information on the potential of different chemical and physical methods (heat shock, mechanical damage, $\mathrm{CsCl}$ incubation) that can be applied to artificially induce $\mathrm{RD}$ of medusae and medusa buds in two hydrozoan jellyfishes ( $T$. dohrnii and $H$. carnea). Bioassays were planned to assess the flexibility of the above-described time of irreversible medusa determination during bud development and the possibility to influence the rate of complete polyp reformation.

\section{Results}

\section{Reverse development in Turritopsis dohrnii}

Medusae of T. dohrnii were observed during the course of reverse development (RD). Chronological records of RD were not taken, since the time length of the process may vary according to experimental conditions (mainly temperature). Attention was paid to detect morphological changes and discriminate among different stages of reverting medusae and buds. Different RD stages were distinguished (Fig. $2 \mathrm{~A}-\mathrm{K}$ ) in two main time frames, corresponding to two consecutive processes: the reduction of medusa features, followed by the formation of polyp structures. A summary of these RD stages is given in Table I.

All typical medusa structures, such as manubrium, ring and radial canal(s), tentacle bulbs and tentacles, umbrella and subumbrella structures are gradually reduced (stage 1 up to stage 4, Fig. 2 A-E). None of these structures are recognizable anymore at the end of medusa shrinkage, the so-called "ball-like" stage 


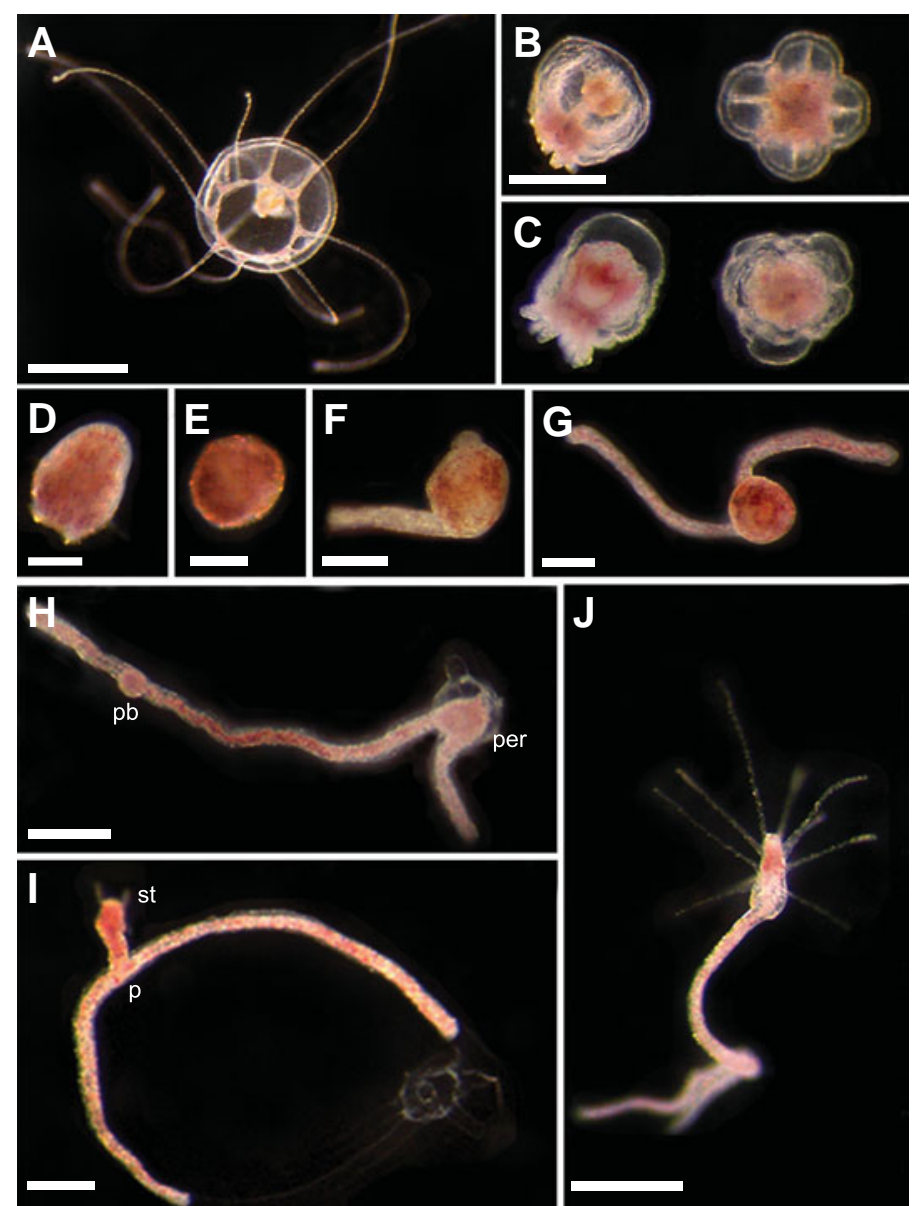

Fig. 2. Stages of reverse development in Turritopsis dohrnii. (A) Control medusa, one-day old. (B) Stage 1, four-lobe clover stage, side and top view. (C) Stage 2, bubble stage, side and top view. (D) Stage 3, side view. (E) Stage 4, "ball-like" stage. (F) Stage 5, outgrowth of stolons. (G) Stage 6, stolons. (H) Stage 7, polyp bud. (I) Stage 8, polyp formation, with small tentacles. (J) Stage 9, adult polyp (see Table 1 for descriptions of stages). Abbreviations: per, perisarc; pb, polyp bud; p, polyp; st, small tentacles; e, exumbrella; s, subumbrella; $m$, manubrium; ra, radial canal; ri, ring canal. Scale bars: $500 \mu \mathrm{m}$ in (A), $300 \mu \mathrm{m}$ in (B, C, H, I), $150 \mu \mathrm{m}$ in $(D, E), 200 \mu \mathrm{m}$ in $(F, G), 400 \mu \mathrm{m}$ in $(\mathrm{J})$.

(stage 4, Fig. 2E); instead, a polyp-typical feature, the perisarc, is newly formed. At this stage, specimens undergoing RD attach to the bottom surface. All the subsequent stages are characterized by steady development of polyp stolons, (Fig. 2 F-J). Finally, new polyps (stage 9, Fig. 2J) are reformed, starting a new hydroid colony.

In few cases, some medusae did not show the potential for a complete transformation into fully formed polyp colonies. Instead, they stopped growing as stolon tissue, regressing back to a balllike structure. Exceptionally, all stolon tissue was reorganized there to build up an undersized, tiny polyp without stolons.

\section{The influence of $\mathrm{CsCl}$ and heat shock on Turritopsis dohrnii medusae}

Cesium chloride is the standard inducing system of metamorphosis, evaluated in Hydractinia echinata at first (Müller, 1973, Müller and Buchal, 1973) and then showed to be effective within a wide range of other marine invertebrates (Carpizo-Ituarte and Hadfield, 1998; Herrmann, 1995; Woollacott and Hadfield, 1996). To find out if chemical cues have any influence on RD, medusae of $T$. dohrnii were incubated in four different concentrations of $\mathrm{CsCl}$ for three hours (see methods). Medusae were kept unfed for the length of the experiment. Stages of RD (see Fig. 2 / Table 1) were grouped and named as follows: MEDUSA (stage 0), freeswimming medusa; REDUCING (stage 1 to 4 ), referred to progressive reduction of medusa structures; $S T O L O N$ (stage 5 to 7), referred to formation of stolons, POL YP BUD (stage 8), referred to the appearance of developing polyps and $P O L Y P$ (stage 9), referred to the presence of feeding polyps with tentacles. The final evaluation of the bioassays was done $5 d$ post-induction $(p-i)$. All concentrations induced RD within 20 hours. After five days $p-i$, three out of the four concentrations of $\mathrm{CsCl}$ significantly improved polyp formation from reversing medusae (Fig 3A), when compared to the untreated control animals. The first polyps were already noticed three days $\mathrm{p}$-i. Only the lowest concentration (14.5 mM CsCl) showed no significant effect compared to the controls relative to the final effect of polyp formation. Also, RD in controls started three days from the beginning of the experiment (data not shown). A second experiment was carried out to evaluate the effect of starvation (see methods). At 48 hours post induction, control medusae were able to feed, while all treated animals underwent at least the early reduction stage. At the end of the experiment only 3 out of 60 control medusae exhibited reduction of the umbrella, without further $R D$, while the remaining medusae showed an increase in size and tentacle number. As in the previous assay, all tested $\mathrm{CsCl}$ concentrations activated $\mathrm{RD}$ within 20 hours $p$-i, with an increasing effect on polyp formation (Fig 3B). After five days $\mathrm{p}-\mathrm{i}$, medusae treated at the lowest $\mathrm{CsCl}$ concentration (14.5 mM) were significantly induced to RD. Medusae exposed to the highest $\mathrm{CsCl}$ concentration $(116 \mathrm{mM})$ showed the highest level of induction, significantly different $(p \leq 0.05)$ from the other concentrations. This may suggest a dose-dependent effect of $\mathrm{CsCl}$, comparably to what is known for larval metamorphosis.

In parallel with the first bioassay for $\mathrm{CsCl}$ concentrations, another metamorphosis-inducer factor (Kroiher et al., 1992), i.e. heat shock, was tested for its influence on RD. The evaluation of these experiments was done as described for the bioassays with $\mathrm{CsCl}$. Polyp bud and polyp formation was significantly increased by all different heat treatments (Fig. $3 \mathrm{C}$ ) when compared to starved controls. Turritopsis medusae were able to undergo RD after short exposures to temperatures up to $37^{\circ} \mathrm{C}$. The $37^{\circ} \mathrm{C}$ treatment even resulted in the highest score of RD.

\section{Reverse development in Hydractinia carnea medusa buds}

According to available information, RD may occur in $\mathrm{H}$. carnea only in isolated, early stages of medusa bud development (Frey, 1968, Schmid, 1972). We isolated normal development (ND) medusa buds from stage 4 to stage 8 (Fig. 4 A, C, E) and tested them for their potential of spontaneous RD (Fig. $4 \mathrm{H}$ ) to determine where the point of irreversible medusa determination (see Introduction) occurs as a reference scale for all subsequent induction bioassays.

Medusa buds at ND stages 4 are characterized by manubrium and radial canal development, the entocodon still proliferating; at ND stages 5 , the subumbrellar cavity appears within the entocodon 
by a process of schizocely (Fig. $4 \mathrm{~A}, \mathrm{~B}$ ). Almost all isolated specimens at stages 4-5 (>95\%) underwent RD (Fig. $4 \mathrm{H}$ ). At ND stage 6 , the subumbrellar cavity of medusa buds is completed (Fig. 4 C, D), whereas at ND stage 7 buds have already started formation of tentacles. Isolated specimens belonging to ND stages 6-7 showed to undergo RD in most cases (Fig. $4 \mathrm{H}$ ) but a few specimens either arrested development or continued the normal ontogeny to form undersized complete medusae. No isolated $H$. carnea medusa buds at ND stage 8-9 (i.e. buds with advanced tentacle development) (Fig. 4 F) spontaneously underwent the process of RD (Fig. $4 \mathrm{H}$ ). Therefore the point or time of irreversible medusa determination is established approximately when the buds reach the morphological stage 8-9 of normal development. All further induction experiments on $H$. carneabuds were performed with specimens at stage 8 of development to evaluate if the assayed treatments had any influence on the determination point.

\section{The influence of $\mathrm{CsCl}$ and needle treatment on reverse development in Hydractinia carnea}

We tested separately the effects of $\mathrm{CsCl}$ and mechanical damage ("needle treatment") on isolated medusa buds at ND stage 8 . Both treatments significantly induced RD and stolon formation in more than $20 \%$ of buds (Fig. 5 A-D and Fig. 5 E; $\mathrm{P} \leq 0.001$, in both $\mathrm{CsCl} 29 \mathrm{mM}$ and "needle" treatments). Thus, by artificial induction the time of medusa determination or irreversibility point can be shifted forward and the stage 8 buds gain the potential to undergo reverse development as well. In both needletreated and cesium-incubated specimens, RD initiates within the first $30 \mathrm{~h} \mathrm{p-i}$; afterwards, no further increase of RD can be detected (Fig. 5 F). In comparison, the normal development of medusa buds into medusae is increasing with time (Fig. $5 \mathrm{G}$ ).

Activation of RD in liberated medusae of $H$. carnea was also tested by $\mathrm{CsCl}$ treatment (Fig. 6). A process of morph reversal seemed to be inducible by low $\mathrm{CsCl}$ concentrations $(14.5 \mathrm{mM}$ and $29 \mathrm{mM}$ ), but it lead only to ball-like stages (Fig. $6 \mathrm{H}$, I), without further progression to polyp formation. Transforming specimens arrested at this stage and survived for about 2 weeks. Nevertheless, adhesion to the substrate of such ball-like stage was not clearly observed. Except for the adhesion to the substrate, the course of transformation up to the ball-like stage of $\mathrm{H}$. carnea medusae was similar to T. dohrnirreverse development. Comparably, in some reversing $H$. carnea specimens the subumbrella and the manubrium turned outside (Fig. $6 \mathrm{~F}$ ), as observed also in T. dohrnii(Piraino et al., 1996). In some cases, medusae did not even reduce their tentacles (Fig. $6 \mathrm{H}$ ).

The first significant differences in $\mathrm{CsCl}$-treated animals compared to the controls were detected after $3 d p$-i. The number of specimens undergoing morphological changes increased up to $18 \%$ at the lowest $\mathrm{CsCl}$ concentrations (Fig. $7 \mathrm{~A}$ ). The survival of specimens remained constant throughout the experiment at the two lower concentrations $(14.5 \mathrm{mM}$ and $29 \mathrm{mM} \mathrm{CsCl}$ ) and the controls whereas all animals died in the highest tested $\mathrm{CsCl}$ concentrations (58 $\mathrm{mM}$ and $116 \mathrm{mM} \mathrm{CsCl}$ ) (Fig. $7 \mathrm{~B}$ ). The highest concentrations rapidly produced toxic effects leading to cell and tissue degeneration (breakdown of the manubrium, generalized disaggregation of canal system and subumbrellar layers) (Fig. 8 A) and medusa-distinctive organs were soon undistinguishable (Fig. 8 B-D). On the contrary, medusa structures of different
A

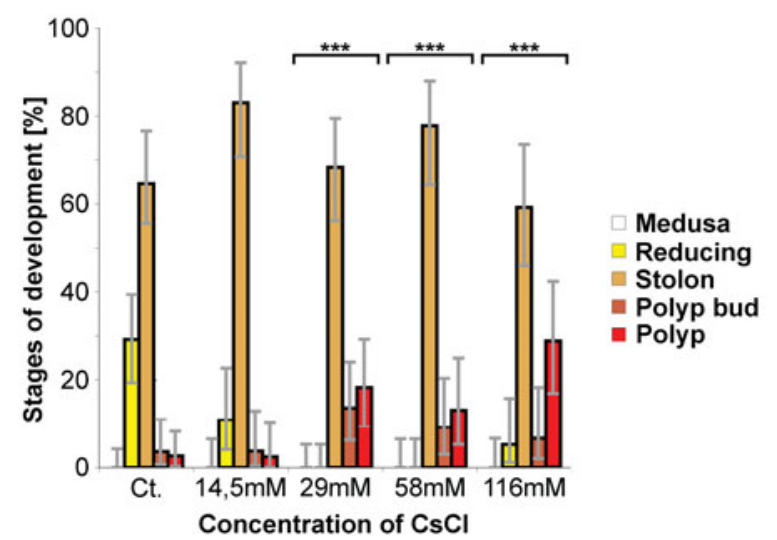

B

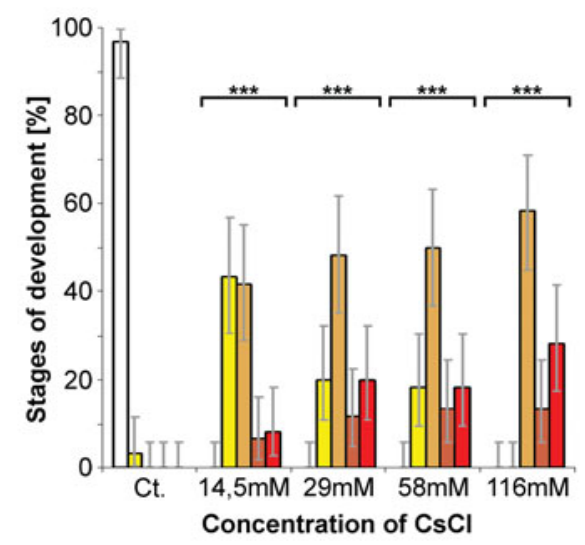

C

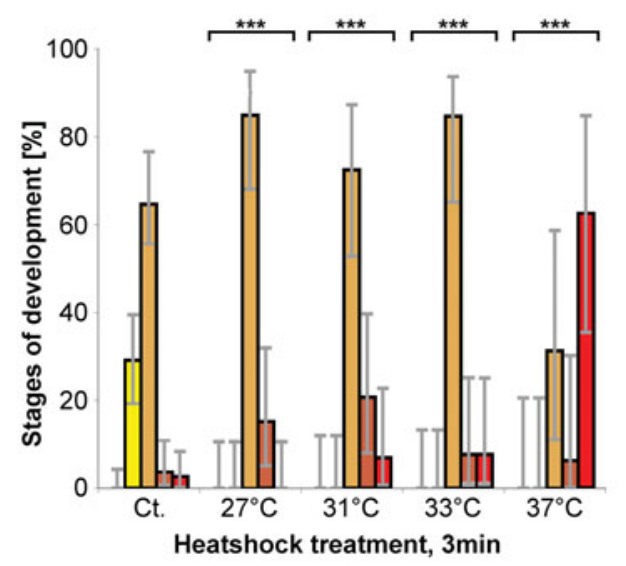

Fig. 3. The influence of $\mathrm{CsCl}$ and heat shock on reverse development and polyp formation of Turritopsis dohrnii (116 $\mathrm{h}$ post induction). $(\mathbf{A}, \mathbf{B}) \mathrm{CsCl}$ increases the possibility of reverse development and polyp formation significantly $(29 \mathrm{mM}, 58 \mathrm{mM}$ and $116 \mathrm{mM} \mathrm{CsCl}$ compared to controls). In (B) animals were fed during the time of the experiment. Notice the large difference in the values from control specimens. Feeding keeps healthy: the control specimens of (B) are more stable in the medusa stage, confirming that starvation activates RD (Piraino et al., 1996). (C) Significant increase of reverse development and polyp formation by heat shock treatment compared to the control. Significance is given by $\left[{ }^{* *}\right] P \leq 0.001$, bars show $95 \%$ confidence level. Abbreviations: ct, control; Reducing, RD stage 1-3. 

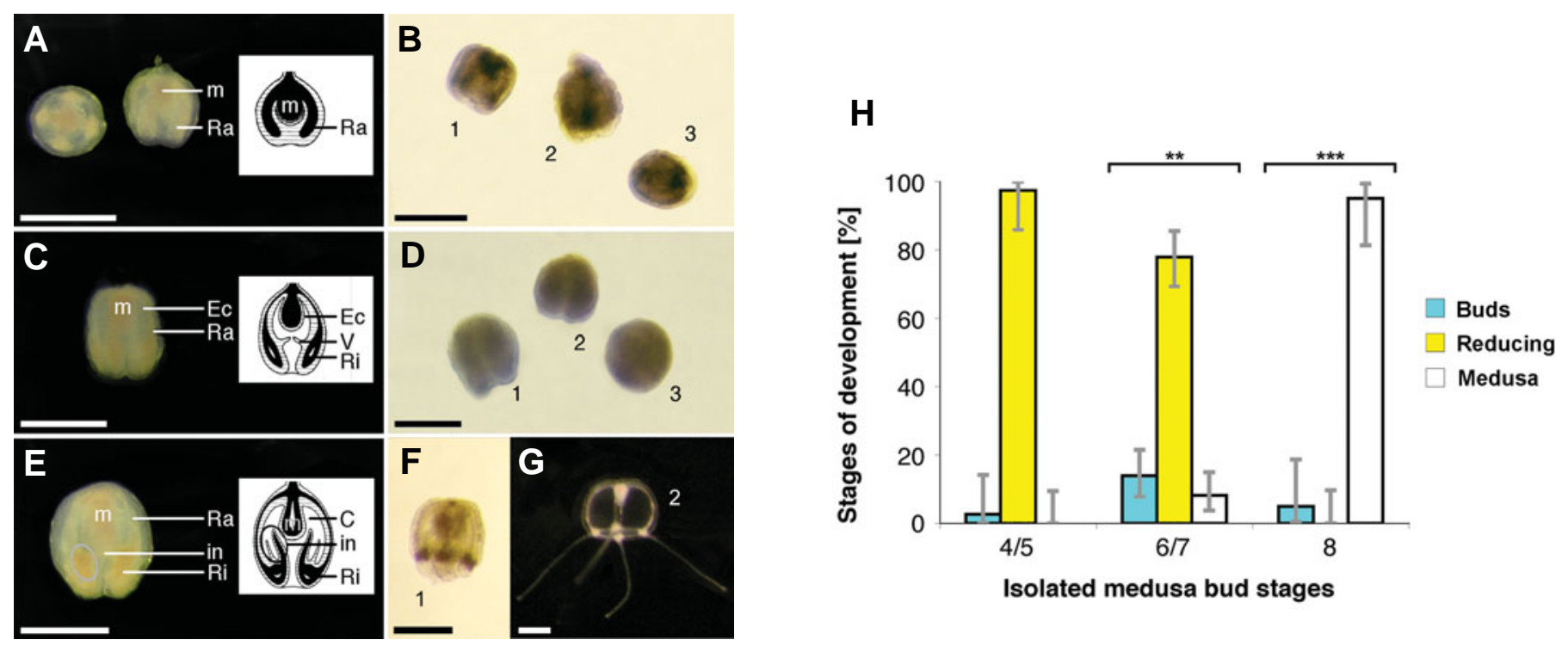

Fig. 4. The fate of untreated isolated medusa buds of various normal developmental stages of $\boldsymbol{H y d r a c t i n i a}$ carnea. (A,B) Fate of medusa buds isolated at normal developmental (ND) stages 4-5. (A) ND stage 4, top and side view. (B) 1, isolated medusa bud; 2, initial RD stage; 3, RD "ball-like" stage. (C,D) Fate of medusa buds at ND stages 6-7. (C) ND stage 6, side view. (D) 1-2, RD initial stages; 3, RD "ball-like" stage. (E,F,G) Fate of isolated medusa buds of ND stage 8. These medusa bud do not undergo reverse development. (E) ND stage 8, side view. (F) Isolated medusa bud. (G) Fully functional small medusa. (H) Spontaneous RD of isolated medusa buds (72 h after isolation). Nearly all medusa buds at young stages of development (ND stage 4/5) undergo RD, but the number of reversing specimens significantly decreases when buds are isolated at older stages of development (ND stages 6/7). Medusa buds of stage 8 develop into small functional medusa. Significance compared to ND stage 4/5: ND stage 6/7: [**]P $\leq 0.005$ and ND stage 8: [** $\left.{ }^{*}\right] P \leq 0.001$. Bars show 95\% confidence intervals. Number of animals: ND stage 4/5: $n=37 ; N D$ stage 6/7: $n=113: N D$ stage 8: $n=36$. Legend: Reducing - RD stages up to ball-like stage. Scale bars: $200 \mu \mathrm{m}$.

specimens followed the same course of reduction during the path of morphology reversal: at first the mesoglea shrank and the subumbrella plus radial canals melted together with either the manubrium (Fig. 6, msra) or the ring canal and tentacle bulbs (Fig. 6 , sritb), only afterwards fusing all together into the ball-like stage.

\section{Discussion}

\section{Timing of developmental potentials}

Earlier work on Hydractinia carnea(Frey, 1968; Schmid, 1972) indicated that medusa budding is marked by two distinct ontogenetic times, designating borderlines between distinct developmental potentials. The time of autonomous medusa bud development (or autonomy point, see Introduction) represents the stage of bud development when isolated buds may proceed with the assembly of the medusa bauplan, without undergoing RD. Corresponding to the stage 3-4 of $H$. carneamedusa budding, this point seems to coincide with the time of formation of the manubrium anlage and the early appearance of the subumbrellar cavity. This develops within the medusary nodule, or entocodon, a third cell layer separated from endoderm and ectoderm by extracellular matrix (Boelsterli, 1977) and provided by an organizer capacity in transplantation experiments (Reisinger, 1957). At this stage, the entocodon starts to differentiate into different cell types (striated muscle, smooth muscle, RF-amide positive cells, ectoderm of manubrium), which will compose the subumbrellar lining of the cavity (Seipel and Schmid, 2005). Myofilament synthesis starts for the first time in the interradial sectors of the basal entocodon and later spread to the radial parts, i.e. underneath the radial canals and to the apical part of the entocodon, where the velum will be formed (Boelsterli, 1977).

The time of medusa determination (or point of irreversibility) is a second moment in bud development standing for a barrier between alternative ontogenetic trajectories. In $\mathrm{H}$. carnea, this point is coincident with the stage 8 of normal bud development, which occurs when the final differentiation of striated muscle cells is completed by the enlargement and thickening of myofibrils (Boelsterli, 1977). Only in later stages 9-10, the swelling of mesoglea will produce deformation and final displacement of the subumbrellar muscle cells, whose contraction will start because of the formation of desmosome-like intercellular junctions. As mentioned, isolated buds from stage 8 have usually lost the potential for RD and they eventually develop into fully functional, but smaller medusae.

Our observations offer additional information about the activation of RD and the determination of borderlines between the developmental potentials. The onset of RD seems to be associated to stress-related events affecting structural or functional integrity of cells and/or tissues. In T. dohrnii, CsCl treatments (see Fig. 3) cause a dose-dependent disruption of the functional integrity of one or several medusa cell types (nerve cells, muscle cells), probably by depolarization of cells and impairment of ion channels (Müller and Leitz, 2002). $\mathrm{Cs}^{+}$and other monovalent cations are known to trigger larval metamorphosis by depolarization processes probably via $\mathrm{Na}^{+} / \mathrm{K}^{+}$-ATPase in Hydrozoa (Müller, 1973, Müller and Buchal, 1973) and several other marine invertebrate taxa, like brachiopods (Freeman, 1993), molluscs (Todd et al., 1991) and echinoderms (Cameron et al., 1989). When $T$. 

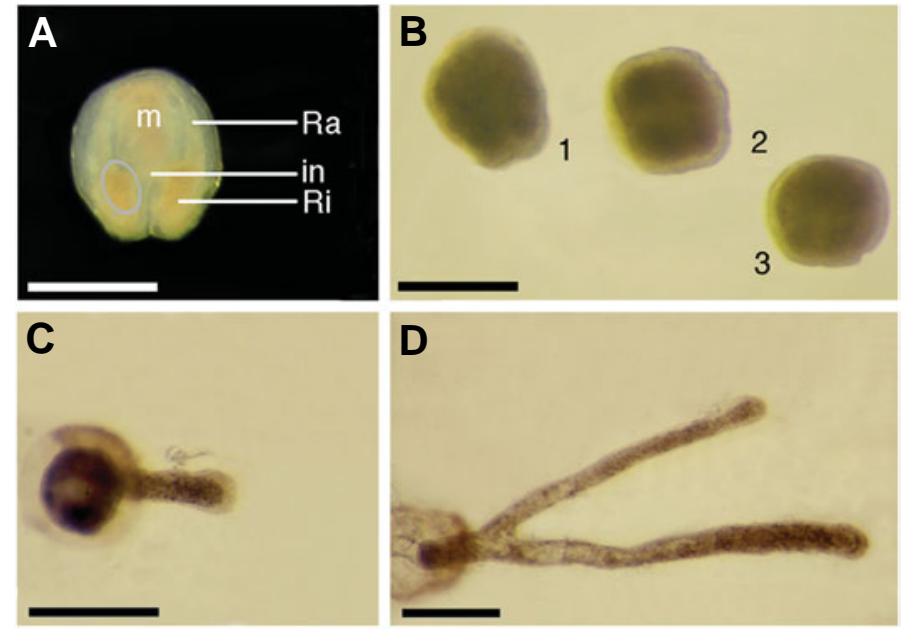

$\mathbf{F}$

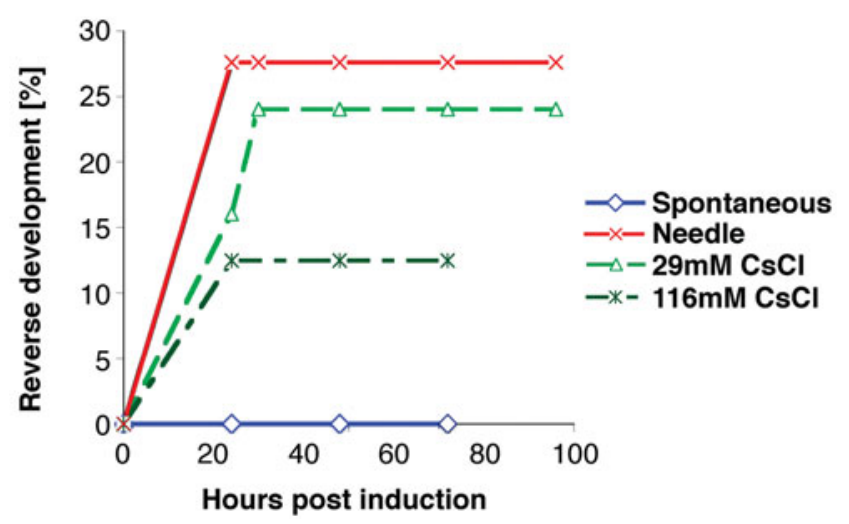

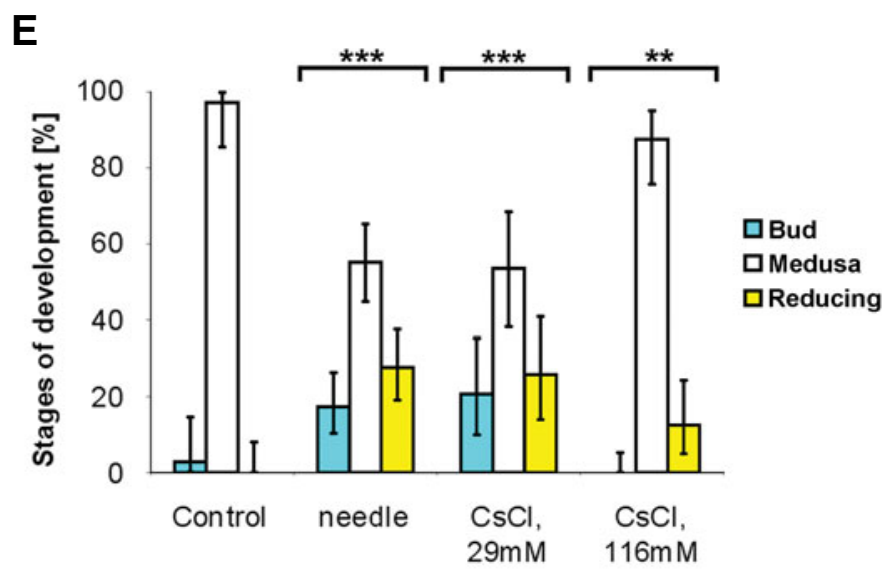

Treatment

G

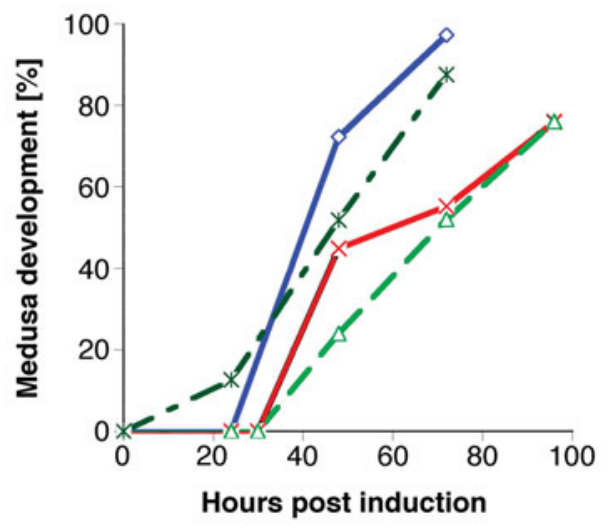

Fig. 5. Artificial induction of reverse development (RD) from isolated developing medusa buds of (stage 8) of $\mathbf{H y d r a c t i n i a}$ carnea. (A) Description of medusa bud stage 8, side view (see also Fig. 4 E). (B) The fate of treated animals: (1) RD initial stage, side view; (2) RD initial stage, top view; (3) RD advanced, "ball-like" stage. (C) Stolon growth from RD "ball-like" stage. (D) Elongation of stolons, the complete material of the former "ball-like" stage is transferred to stolon material, notice the "empty" perisarc. (E) Occurrence of RD in medusa buds isolated at stage 8 of ND and induced by treatments (72 h post induction). (F) The time course of RD. Within $30 \mathrm{~h}$, medusa buds undergo RD. After this time point no changes are visible. (G) Medusa development. In comparison, the development of fully functional medusae is rather progressive. The number of developing medusa constantly increases throughout the whole time period. Significance levels (E) compared to control with needle treatment and $29 \mathrm{mM}$ CsCl, $\left[{ }^{* *}\right] P \leq 0.001$ and $116 \mathrm{mM} \mathrm{CsCl}\left[{ }^{*}\right] P \leq 0.005$. Bars show 95\% confidence intervals. Animal numbers: control, $n=36 ; n e e d l e, n=98 ; 29 \mathrm{mM}$ CsCl, $n=46 ; 116 \mathrm{mM} \mathrm{CsCl}, n=56$. Legend (A-D): $\mathrm{m}$, manubrium; Ra, radial canal; Ri, ring canal; in, inward folding of velum and tentacle buds; ( $E$ ) reducing, $R D$ stages up to the ball-like stage. Scale bars: $200 \mu m(A, B, C, D)$.

dorhniimedusae were unfed, the response to $\mathrm{CsCl}$ was partially obscured by the late activation of RD in control animals from three to five days $p-i$ (Fig. $3 \mathrm{~A}$ ). By feeding the animals during the bioassay, the effect of $\mathrm{CsCl}$ on treated animals was more clearcut and dose-dependent (Fig. 3 B). In both cases, a short exposure time (three hours) to any of the tested $\mathrm{CsCl}$ concentrations quickly induced RD, appearing as visible morphological changes within 20 hours after $p-i$

The inductive potential of $\mathrm{CsCl}$ on $\mathrm{RD}$ of $H$. carnea buds was also unambiguous, even though not clearly related to concentration as in T. dohrnii(Fig. 5). Contrary to expectations, incubation with $\mathrm{CsCl}$ was effective also with liberated medusae of $H$. carnea, leading to the formation of reversing stages. $\mathrm{CsCl}$ effects on $H$. carnea medusae were quite similar to the normal, gradual reduction/death stages (Schmid and Tardent, 1969). Degeneration started with the reduction of the bell, however, when ball-like structures were formed, they never attached to the substrate as in $R D$. The shrinkage of the bell is also a typical feature of RD in T. dohrnimmedusae; therefore it should not be used as a distinctive character, per se, to discriminate between medusa death and RD. The shrinkage of the bell caused $H$. carneajellyfish to settle on the bottom, being unable to swim, as observed in T. dohrnii. In this last species, perisarc formation and adhesion to the substrate occurs, followed by the formation of stolons and polyps, the conclusive evidence of a complete RD. In the experiments with $H$. carnea medusae, formation of a perisarc layer and adhesion to the glass surface in the transforming medusae was never detected. However, the ball-like stages deriving from the medusae remained unaltered, like a remnant cyst, for the following 10-14 days. Only afterwards, when bacterial growth overcame, the ball-like stages 
were rapidly disintegrated. Such a prolonged steady state of the ball-like stages is highly different from the commonest pattern of degeneration observed in several species of hydrozoans (Piraino, unpublished observations on several species of Zanclea, Dipurena, Bougainvillia, Eleutheria, Eirene, Clytia, Gastroblasta, Eugymnanthea). The shrinkage of bell in most species is followed within few hours by fast bacterial growth and disintegration of all tissues occurs within 36-48 hours. Two species showed a comparable developmental arrest in the ball-like stage: Laodicea undulata and Amphinema sp., two species retaining the potential for full reverse development (De Vito et al., 2006; Miglietta M.P., personal communication). Nevertheless, further investigations are needed to clarify the true nature of the cesium-inducible regression of liberated $H$. carnea medusae.

The effect of increased temperature on the integrity of polyps and medusae of $H$. carnea was described by Schmid et al., (1981), who demonstrated that animals shortly exposed (10-20 minutes) to temperatures as high as $35^{\circ} \mathrm{C}$ can be dissociated into single cells, which can re-aggregate and regenerate polyp and medusa structures according to their origin. However, polyp structures from dissociated medusa cells could not be obtained. Schmid et al., (1981) suggested that heat may alter the extracellular matrix to initially cause cell detachment, but the ECM retains the ability to provide further cell attachments. Alternatively, the cell cytoskeleton components may be reversibly affected by heat. We showed here that short heating treatments can induce $T$. dohrniimedusae to RD, comparably to what is already known for other sub-lethal treatments (bud isolation, starvation, osmotic shock, mechanical stress) and to senescence, which may all affect the physical integrity (Piraino et al., 1996).

In T. dohrniithe RD ability is observed throughout the ontogeny and the life span of the liberated medusa. On the other hand, in H. carnea liberated medusae normally do not have the capability to undergo reverse development, which is known only in young isolated medusa buds, transforming back to the ball-like stage or to stolons. Only in a low number of cases, the development of a polyp structure was observed (Frey, 1968, Schmid, 1972). Older experiments (Frey, 1968, Schmid, 1972) proved that a mechanical stress (a "squeezing" treatment) applied on the isolated buds increased the number of reverse developing specimens and even allowed older stages to undergo RD by shifting forward the ontogenetic point of medusa determination. To standardize the amount of mechanical damage and the loss of integrity, we reproduced those experiments by perforating $H$. carnea medusa buds at stage 8 of normal development with a sharp needle, drilling through the centre of the medusa bud, in order to destabilize the integrity of the manubrium and its component tissues. The entocodon layer, already lining the subumbrellar cavity and the manubrium, is primarily wounded by the needle treatment. Our experiments confirmed that the loose of structural integrity of medusa buds at stage 8 causes the shift of the point of irreversibility (time of medusa determination), providing new evidence in favour of the key role of entocodon and its derivatives for the determination of medusa structures. Schmid (1972) demonstrated that physical injury on isolated H.carneabuds, by single or repeated squeezing with forceps, lead to higher rates of $R D$. This may suggest that it is not the wound healing and regeneration per se to influence the potential for RD, but the amount of physical damage caused on the buds. Furthermore, the location of mechanical damage is essential: regeneration of excised tentacles in $T$. dohrnii medusae does not induce RD. At last, our experiments showed that the needle treatment on stage 8 buds may shift the point of irreversibility and that this effect is comparable to induction by $\mathrm{CsCl}$ (Fig. $5 \mathrm{E}$ ).

Early isolated $H$. carnea medusa buds easily undergo RD, but rarely form polyps. At the opposite, liberated medusae cannot undergo $\mathrm{RD}$ or might be induced (by $\mathrm{CsCl}$, see above) only to a basic regression step. On the contrary in T. dohrniithe potential
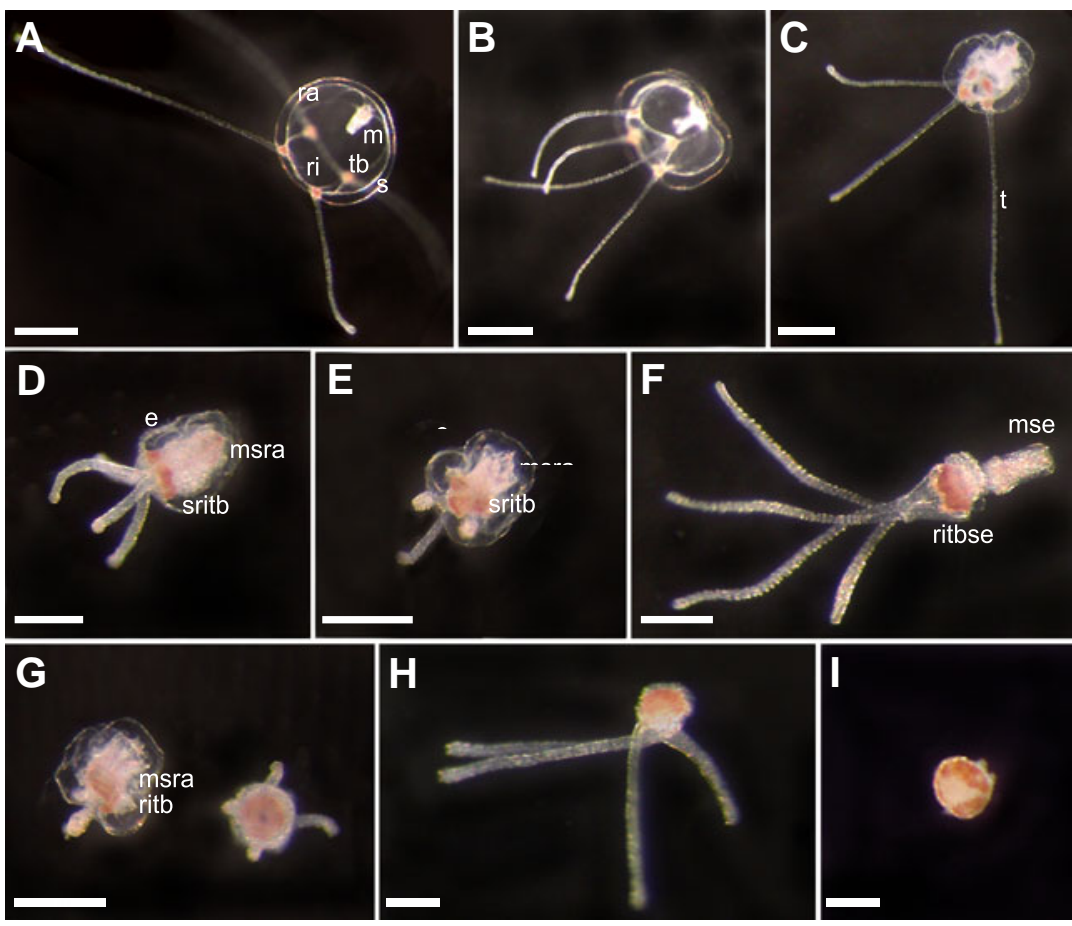

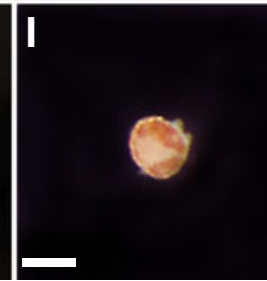

Fig. 6. Stages of RD of Hydractinia carnea medusa buds (compared to T. dohrnii). (A) Liberated medusa of $\mathrm{H}$. carnea with the description of medusa organs. (B,C) Stage 1. Beginning of reverse development, destabilization of the mesoglea alters the bell shape (treatment $29 \mathrm{mM}$ CsCl). (B) The pathway of RD: the exumbrella (e) is still visible, the manubrium reduces, melting together with subumbrella and the upper part of the radial canal (msra). The subumbrella, ring canal and tentacle bulbs are reduced and fused together (sritb). (D-G) Stage 2. Comparable to stage 2, multi-lobe stage of T. dohrnii. (D,E) Lateral view; in both pictures a similar aggregation of medusa organs can be seen, which is comparable to Fig. 6 B. (F) Manubrium everted to the outside; the aggregation of former medusa organs is verified: the former manubrium is combined with the ex-and the subumbrella (mse), whereas the ring canal / tentacle bulbs are associated with the lower part of the sub- and exumbrella (ritbse). (G) Side and top views: all former medusa organs are combined (msraritb). $\mathbf{( H , I ) ~ S t a g e ~ 3 . ~ " B a l l - l i k e " ~ s t a g e . ~ ( H ) ~ I n ~ a ~ f e w ~ c a s e s , ~ t e n - ~}$ tacles were not reduced. (I) Ball-like stage, comparable to T. dohrnii (Fig. 2E). Legend: $m$, manubrium; s, subumbrella; $e=$ exumbrella; $r a=$ radial canal, $r i=$ ring canal; $t b$, tentacle bulb; $t$, tentacle; msra, merged structures formally being $m, s, r a$; sritb, merged structure formally being $s, r i$, th. Scale bars, $200 \mu \mathrm{m}$. 
for RD is full and conserved through the ontogeny and life span of the medusa. But why does $H$. carnea have a lower reversal potential than T. dohrni?

A first reason might be that the amount of cells in early medusa buds may start stolon formation but it is insufficient to form polyps. However, the switch of the irreversibility point in $H$. carnea buds showed that even older, larger buds, which are activated for RD, did not form polyps as well. This indicates that the potential to form polyp is not simply linked to the amount of available cells for RD. Also, a genetically based disparity may stand for the different RD potential between $H$. carnea and $T$. dohrnii. It might be that the final part of the process, i.e. building up polyp structures, needs additional signals that in $\mathrm{H}$. carnea are not provided or activated by the artificial induction of the RD process. Therefore, the lowered potential for RD in $H$. carnea might be due to a combination of these reasons. It can be gradually modified through the development of the medusa, which goes in parallel to differentiation of medusa typical features, a process driven by the entocodon layer. At early stages, the potential for RD is full, but it cannot withstand the amount of cells required for polyp formation. Middle stages of bud development (5-6-7) can undergo reverse development and form polyps: the potential is still intact and can be expressed with the possibility to produce polyps. At this stage, the entocodon derivatives are not fully differentiated and the mesoglea swelling is not occurred yet. At later stages, the amount of cells would be sufficient, but the potential for RD switched off.

A
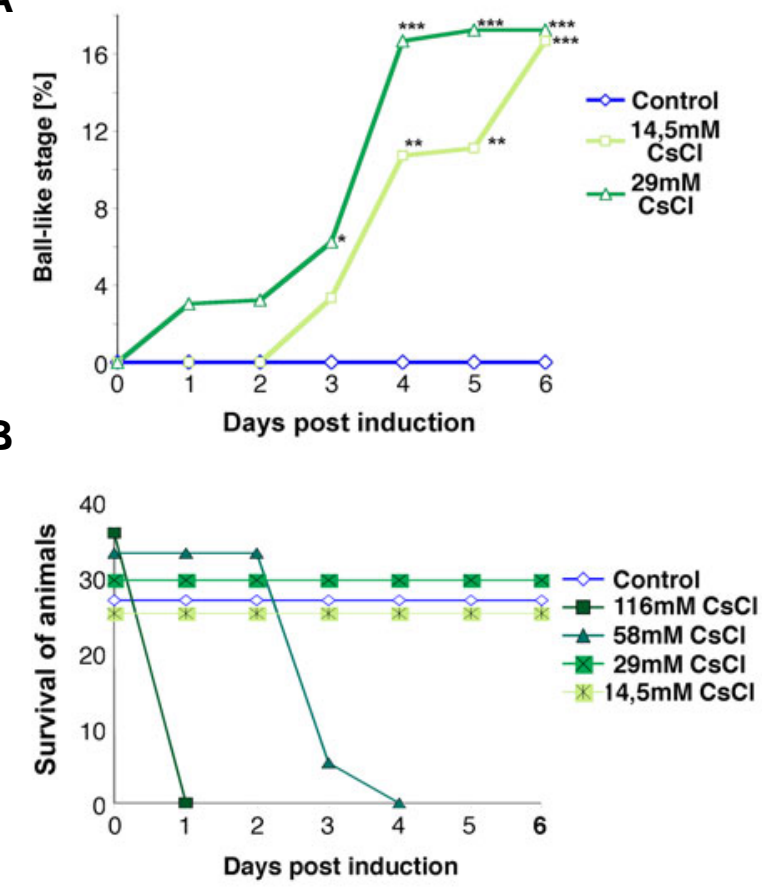

Fig. 7. The course of reverse development in $\boldsymbol{H}$. carnea adult medusa. (A) Effect of two concentrations of $\mathrm{CsCl}$. The earliest significant differences are visible after 3 days post induction $(29 \mathrm{mM} \mathrm{CsCl).} \mathrm{(B)} \mathrm{Survival}$ of animals: $116 \mathrm{mM}$ and $58 \mathrm{mM} \mathrm{CsCl}$ turned out to have a toxic effect on the animals, whereas the number of surviving specimens was constant with the other two treatments comparable to the control. Significance $(A)$ is given by: $\left[{ }^{*}\right] P \leq 0.05,\left[{ }^{*}\right] P \leq 0.01,\left[{ }^{* * *}\right] P \leq 0.001$
This may be due to the complete differentiation of medusa cell structures, especially those deriving from the entocodon layer. Treatments altering the physical integrity of medusa typical features can reactivate the RD programme only to the initial regression steps.

\section{Reverse development and metamorphosis}

In several metazoans (e.g., planarians, nemerteans, bryozoans and compound ascidians) starvation or stress may lead to a temporary decrement in size and cell number ("de-growth") to form survival stages from which new individuals or colonies will be reformed later (references in Piraino et al., 1996; Minelli, 2003). Besides the formation of resting cysts from developing embryos, several invertebrate taxa (e.g., nematodes, rotifers, tardigrades) are known for their ability to rest in temporary dormancy stages of adult specimens (Ricci, 1998; Womersley et al., 1998; Bertolani et al., 2004). However, in all these cases a morphological reversal, including replacement of cell types, does not occur.

Cnidarians attain RD in many cases by a process requiring extensive tissue and cell rearrangements. During hydrozoan $\mathrm{RD}$, the multi-layered medusa stage (Boero et al., 1998, Boero et al., 2005, Seipel and Schmid, 2005) transforms back into the earlier stage in the life cycle, i.e. the two-layered post-larval polyp stage. Reverse development of $T$. dohrniimedusae into polyps has been interpreted as a kind of "reverse metamorphosis" as it occurs by drastic morphological changes and coordinated switches of stage-specific cells and structures (Piraino et al., 1996, Piraino et al., 2004).

From sponges to chordates, the term metamorphosis usually refers to a significant change during animal development in body structure and organization (increase in body size and anatomical complexity) involving growth and differentiation and it is most commonly referred to the change from a larval state to an adult state. Larvae developing into juveniles or into larvae of higher orders (like in trematode life cycles) require complex morphogenetic events and re-establishment of axial patterning, as it occurs during RD.

A first evidence of parallelism between metamorphosis and $\mathrm{RD}$ can be detected in the occurrence of apoptosis in both processes. The involvement of apoptosis in the RD process of T. dohrniimedusae has been already documented (Carlà et al., 2003). It has been recently observed that apoptotic staining (TUNEL assays) starts from the ectoderm of ring canal, tentacular bulbs and tentacles and it extends later to exumbrellar ectoderm (Valentini, 2006).

Also larval metamorphosis requires apoptosis in hydrozoans and in several other taxa. Planula metamorphosis in the hydrozoan Hydractinia echinata requires proliferation and differentiation of new cell types but also the dismissal of some larval cell types by apoptosis (Seipp etal., 2001, 2002). Apoptosis ablates cells that are no longer needed such as muscles and neurons essential for larval locomotion in insects or the amphibian tadpole tail. Also, ecdysone pulses trigger the apoptotic destruction of salivary glands during Drosophila metamorphosis (see Meier et al., 2000; Baehrecke, 2002 and references therein). Metazoan larvae (from cnidarians to chordates) treated with inhibitors of caspases are prevented to undergo metamorphosis (Seipp et al., 2006 and references therein). 

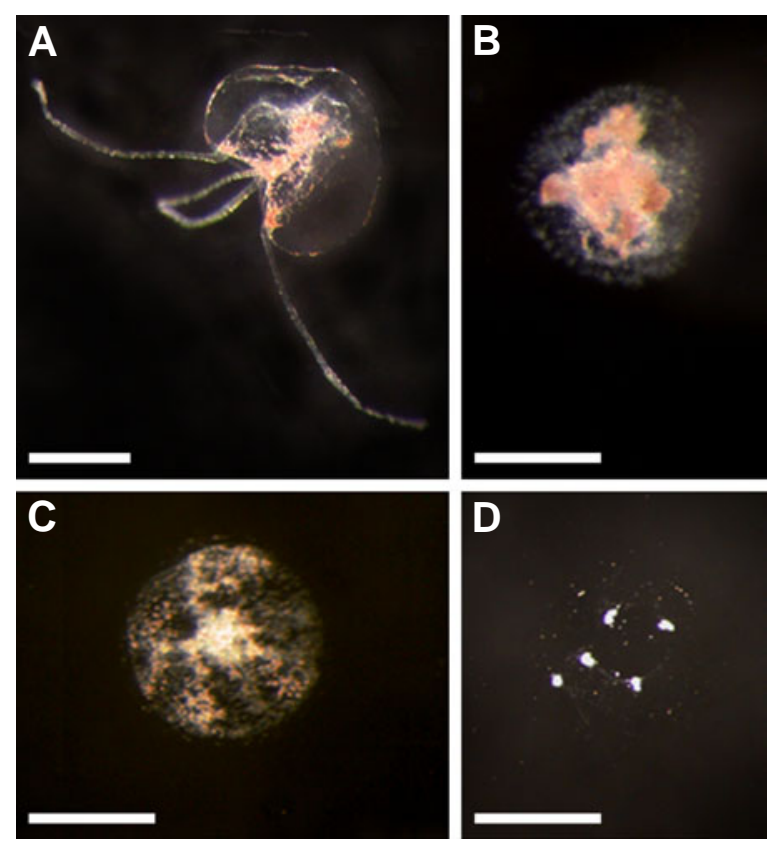

Fig. 8. The course of a disintegrating medusa of $\boldsymbol{H}$. carnea caused by high concentrations of CsCl. (A) Uncoordinated reduction of medusa structures at $116 \mathrm{mM} \mathrm{CsCl}$ concentration (compare to stage 1, Fig. 6 B,C). (B-D) Continuation of disintegration. (D) Only dead cell aggregates are still visible as remnants of tentacle bulbs and manubrium. Scale bars, $200 \mu \mathrm{m}$.

Similarities between larval metamorphosis and RD include also artificial inducers. Cesium ions and heat shock act as powerful artificial inducers for larval metamorphosis (reviewed by Müller and Leitz, 2002), both influencing the formation of heat shock proteins (Kroiher et al., 1992). Piraino et al. (1996) used a prolonged incubation at $27^{\circ} \mathrm{C}$ to induce RD in $T$. dohrnii medusae, while Carlà et al. (2003) recorded the efficacy of incubation for $30^{\prime}$ at $30^{\circ} \mathrm{C}$. We showed here that short-term exposure (3') at temperatures from $27^{\circ} \mathrm{C}$ up to $37^{\circ} \mathrm{C}$ were all successful in producing RD in medusae, the treatment with the highest temperature $\left(37^{\circ} \mathrm{C}\right)$ giving origin to the highest number

Fig. 9. Comparison of reverse development and metamorphosis. Induction: possible induction pathways of both processes are labeled, the thickness of arrows indicates the capacity of induction. For reverse development: senescence (probably the natural inducer) and physical stress have a great influence on inducing the process, whereas heat shock and artificial (chemical) inducers are also known. For metamorphosis: the main induction is based on bacterial inducers (natural induction) and on artificial inducers that mimic the process. Heat shock induction is also possible, but probably plays a minor role, according to induction. Stress is not able to induce metamorphosis by itself but increases the rate of metamorphosis upon cesium induction (marked as supporting). It is noteworthy that some induction methods play a role during both processes (like heat shock, artificial inducers, stress), but there are also inducers that only support one of the processes (reverse development: senescence; metamorphosis: bacterial inducers). After induction, larva and medusa structures are reduced up to an intermediate developmental stage, the ball-like stage. After this stage, the development of polyp structures begins. During reverse development, formation of stolons occurs before the development of hydranth body and tentacles. During metamorphosis, stolon formation and hydranth development become synchronous, after formation of the primary polyp. of full reversion (polyp formation). The role of HSPs in RD needs to be elucidated yet, since several members of the HSPs gene family have been cloned from activated $T$. dohrniimedusae (Schmich et al., unpublished data). In addition, we showed here for the first time that by incubation with $\mathrm{Cs}^{+}$ions RD is generally activated both in $H$. carneaisolated medusa buds and T. dohrnii medusae. In the latter species RD seems definitely activated in dose-dependent manner.

Specific induction pathways are also demonstrated in one or the other process. Larval metamorphosis is naturally induced by an external signal released by marine bacteria (e.g. Pseudoalteromonas espejiana and other-Alteromonas and Pseudoalteromonas spp. for Hydractinia echinata; see Müller, 1969; Leitz and Wagner, 1993; Kroiher and Berking, 1999). Without natural or artificial induction, $H$. echinata larvae kept in sterile filtered seawater will never metamorphose, since, in the absence of bacteria, stand-by signals are not removed for the activation of pathways for polyp development (see Müller and Leitz, 2002 for review on metamorphosis induction, in detail: Berking, 1988 for effects of taurine and Berking, 1986a, 1986b, 1987 for trans-methylation processes). In comparison, the induction of RD can be naturally started also by endogenous signals. For instance, RD of T. dohrniimedusae is initiated by senescence (i.e. sexual maturity) or by starvation of immature specimens (Piraino et al., 1996). In most cases spontaneous $\mathrm{RD}$ in other cnidarians is driven by exogenous signals, especially temperature (Piraino et al., 2004 for a review of cases). In general, data from our different bioassays suggest that any external or internal stress causing the destabilization of the physical/physiological integrity of specimens can induce RD.

On a morphological basis, following the initial activation, basic events are paralleled in metamorphosis and reverse development (Fig. 9): the original structures (planula or medusa) are reduced to an intermediate ball-like stage characterized by poorly differentiated cells and by a protective chitinous perisarc. As mentioned, programmed cell death is involved in both RD and metamorphosis. In H. carneamedusae, it is known that striated muscle cells can transdifferentiate up to 8 different new cell types (Schmid, 1992) and probably such cellular

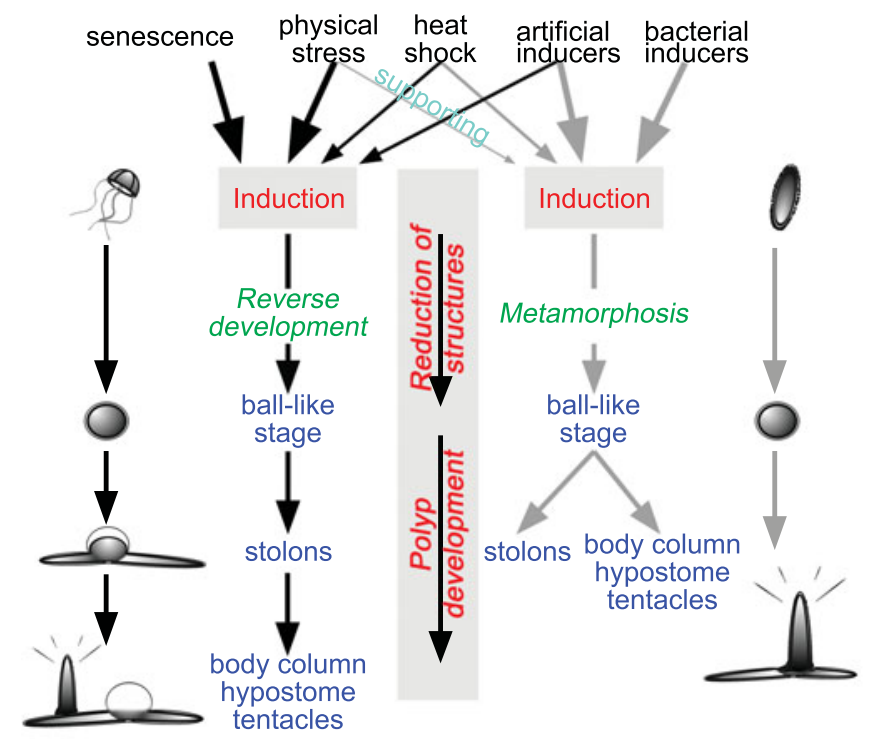


multipotency plays also an essential role during RD. In $T$. dohrnii, synthesis of new cell types from interstitial cells was demonstrated to be not sufficient to fulfil $\mathrm{RD}$, requiring the participation of medusa-specialized cells (ectoderm, muscle cells, endoderm of radial canals) to take part to polyp formation by transdifferentiation (Piraino et al., 1996).

During metamorphosis ( $H$. echinata), the planula develops into a primary polyp at first. Developing stolons and new polyps will arise shortly afterwards (Fig. 9). In comparison the ball-like stage typical of RD always develops stolons first and only later polyps will arise. In both cases, the final result is a new colony. However, each planula larva develops from a fertilized egg and is genetically different from any other larva or existing colony. During $\mathrm{RD}$, all medusae deriving from the same parental colony are genetically identical and, therefore, clonal. The same genotype will belong also to the newly formed colonies obtained by RD (for a discussion about the ecological and evolutionary significance of RD, see Piraino et al., 2004; De Vito et al., 2006).

Basic knowledge about processes acting downstream of the induction of metamorphosis is available (for review see Frank et al., 2001; Müller and Leitz, 2002). Neurosensory cells transfer internally the external signal via the phosphatidyl-inositolPKC transduction cascade (Leitz and Müller, 1987). These cells communicate the starting signal of metamorphosis to the whole larval body by secreting, at their axonal terminals, signalling peptides, namely neuropeptides of the GLWamide family, promoting further processes of metamorphosis. Therefore these neuropeptides act as true morphogenes and are essential signalling substances during metamorphosis (Leitz et al., 1994; Schmich et al., 1998 a, b; Plickert et al., 2003). Activation of $\mathrm{PKC}$ is involved also in the initiation of cell transdifferentiation and RD pathways in H. carnea (Schmid and Reber Müller, 1995), but it is still unknown how the initial activation signal is transferred downstream into the whole RD process. In the last years, investigations on $H$. carnea development (e.g.: Müller et al., 1999; Spring et al., 2000; Yanze et al., 2001; Spring et al., 2002; Lichtneckert et al., 2002; Müller et al., 2003; Seipel et al., 2004a,b,c,d; Stierwald et al., 2004; Torras et al., 2004) offered valuable information on key genes acting during medusa development. Studies on differentially expressed genes in normal and reversing medusae of $T$. dohrniihave been recently started to unravel the molecular basis of reverse development and the potential for stage-specific gene activation.

\section{Materials and Methods}

Hydractinia carnea colonies from the Mediterranean Sea (Gulf of Naples) were kept growing attached on glass slides or bowls in a natural seawater aquarium under controlled conditions $\left(T=20^{\circ} \mathrm{C}\right.$, 12:12 $\mathrm{h}$ dark-light cycle). The aquarium was equipped with a regular filter system and ventilated by a separate air pump system. Animals were fed two to three times per week with newly hatched or 2-day old Artemia salina nauplius larvae. During feeding sessions, the glass bowls/slides were transferred into a separate ventilated tank. Feeding time was about 1 hour. Afterwards polyp colonies were cleaned by a gentle water flow to remove egested debris or dead nauplii. Medusae were collected from overnight isolated host cultures and transferred into natural $(0.7 \mu \mathrm{m}$-filtered) seawater (FSW). All further bioassays were performed in FSW. Medusa buds for bioassays were isolated from polyps by means of micro-scissors or surgical blades and sorted by size and morphology, according to Frey (1968) and Boelsterli (1977) to discriminate up to ten stages of normal development (ND), from the first bud appearance (stage 1) to the liberation of a free-swimming medusa (stage 10). Polyp colonies of Turritopsis dohrniiwere collected from the Ionian Sea by scuba diving at the same locality (a small submersed cave at Santa Caterina di Nardò, $2 \mathrm{~m}$ depth). They were hosted in the laboratory as previously described (Piraino et al., 1996).

\section{Bioassays}

Bioassays were designed to assess how the development and fate of the isolated medusa buds or liberated medusae can be experimentally influenced. All bioassays were done in duplicates to confirm the obtained results. The number of tested specimens per bioassay was 30-50. Experiments on liberated medusae were performed on specimens of T. dohrnii and H. carnea, while bioassays on medusa buds at ND stages from 4 to 8 (Frey, 1968, Boelsterli, 1977) were carried out with $H$. carnea only. Medusa buds of $H$. carnea were isolated by cutting the short peduncle connecting with the polyp tissues very close to polyp body to protect the bud surface and to prevent accidental injuries of bud tissues. Detached medusa buds were first sorted by size and afterwards carefully examined for their integrity under a stereomicroscope.

All tested specimens of $H$. carnea were collected from the same colony throughout all experiments and therefore genetic variability among them was assumed to be absent. For each bioassay with $T$. dohrnii, all tested specimens were also obtained from a single colony, but colonies were different for different bioassays.

a) Incubation with CsCl. Medusae were collected in FSW into plastic dishes and incubated for 3 hours with $\mathrm{CsCl}$, added from a $580 \mathrm{mM}$ stock solution to four final concentrations ( $116 \mathrm{mM}, 58 \mathrm{mM}, 29 \mathrm{mM}$ and 14.5 $\mathrm{mM}$ ) and mixed carefully by rotating the Petri dishes. After the incubation, animals were washed three times and transferred in FSW in new Petri dishes, or in larger glass bowls. Bioassays were carried out up to five days from the induction. The decision to score the results after five days was taken in order to detect differences in the formation of fully developed polyps. Performing bioassays with medusae in small Petri dishes allowed easier and faster detection of RD, but to avoid decay of the biological water quality the medusae were not fed during the test. As a consequence, eventually starvation influenced controls. Starvation, in fact, is known as one of the critical factors inducing the spontaneous life cycle reversal in Turritopsis (Piraino et al., 1996). An additional experiment was performed to evaluate the effects of starvation on control animals, by feeding and maintaining the tested animals in larger volumes of FSW (glass bowls, $200 \mathrm{ml}$ each). All experimental animals were fed four hours before the incubation in cesium chloride (four concentrations, see above), 48 and 96 hours after the beginning of the experiment.

b) Heat shock bioassay. Liberated medusa were incubated for 3 min at four different temperatures $\left(27^{\circ} \mathrm{C}, 31^{\circ} \mathrm{C}, 33^{\circ} \mathrm{C}, 37^{\circ} \mathrm{C}\right)$ and cooled down on ice to RT immediately afterwards. Then the animals were transferred in FSW into sterile plastic Petri dishes.

c) "Needle treatment". Medusa buds of $H$. carnea at the ND stage 8 (Frey, 1968, Boelsterli, 1977) were isolated as described above. To induce the process of dedifferentiation in $\mathrm{H}$. carnea buds (Schmid, 1972), a fine stainless steel needle (diameter of the needle tip $=0,1$ $\mathrm{mm}$ ) was stuck into the peduncle remnant, moved through the umbrella and manubrium to the subumbrellar cavity and drawn out. The presence of 'cell clouds' near the point of needle entrance confirmed the disruption of umbrellar and manubrial tissues.

\section{Scoring of reverse development (RD)}

The RD stages were counted under a binocular microscope at different time points after induction and identified according to a scale of RD morphological stages (given in Fig. 2 and Tab. 1). The different RD stages were photographed by digital photo camera OLYMPUS C5050 mounted on a LEICA stereomicroscope MZ12. 
Results of the bioassays were tested for statistical significance by G-test (a log likelihood ratio test; Sokal and Rohlf, 1994) and by choosing the level of $95 \%$ confidence limits (bars). Asterisks express $P$ values: $\left.\left[{ }^{\star}\right] \mathrm{P} \leq 0,1 ;\left[{ }^{* *}\right] \mathrm{P} \leq 0,01 ;{ }^{* * *}\right] \mathrm{P} \leq 0,001$.

\section{Acknowledgements}

We thank the reviewers for their helpful comments, which greatly improved the earliest version of this manuscript. This work was supported by the European Commission (Vth FP, Marie Curie Fellowship Program, contract HPMD-CT-2001-00099), MURST (COFIN andFIRB Projects), the Administration of the Province of Lecce, and the MarBEF European network.

\section{References}

ACHERMANN, J. (1978). Die Medusenentwicklung von Podocoryne carnea M. Sars (Hydrozoa) unter die Wirkung von Actinomycin D und Puromycin. Zool. J. Allg. Zool. Physiol. 82 4: 441-464.

BAVESTRELLO, G., SOMMER, C. and SARÀ, M. (1992). Bi-directional conversion in Turritopsis nutricula. In: Bouillon J, Boero F, Cicogna F, Gili JM and Hughes RS, (eds) Aspects of Hydrozoan Biology. Scientia Marina 56(2-3): 137-140.

BAEHRECKE, E.H. (2002). How death shapes life during development. Nat. Rev. Mol. Cell. Biol. 3: 779-787.

BERKING, S. (1986a). Transmethylation and control of pattern formation in Hydrozoa. Differentiation 32: 10-16.

BERKING, S. (1986b). Is homarine a morphogen in the marine hydroid Hydractinia? Roux's Arch. Dev. Biol. 95: 33-38.

BERKING, S. (1987). Homarine ( $N$-methylpicolinic acid) and trigonelline $(N$ methylnicotinic acid) appear to be involved in pattern control in a marine hydroid. Development 99: 211-220.

BERKING, S. (1988). Taurine found to stabilize the larval state is released upon induction of metamorphosis in the hydrozoan Hydractinia. Roux's Arch. Dev. Biol. 197: 321-327.

BERTOLANI, R., GUIDETTI, R., JÖNSSON, K.L., ALTIERO, T., BOSCHINI, D. and REBECCHI, L. (2004). Experiences with dormancy in tardigrades. J. Limnol.63: $16-25$.

BOELSTERLI, U. (1977). An electron microscopic study of early developmental stages, myogenesis, oogenesis and cnidogenesis in the Anthomedusa, Podocoryne carnea M. Sars. J. Morphol. 154: 259-290.

BOERO, F. (1984). The ecology of marine hydroids and effects of environmental factors: a review. P.S.Z.N. I: Marine Ecology 5: 93-118.

BOERO, F., GRAVILI, C., PAGLIARA, P., PIRAINO, S., BOUILLON, J. and SCHMID, V, (1998). The cnidarian premises of metazoan evolution: from triploblasty, to coelom formation, to metamery. Ital. J. Zool., 65: 5-9.

BOERO, F., BOUILLON, J., PIRAINO, S. and SCHMID, V. (2002). Asexual reproduction in the Hydrozoa (Cnidaria). In: Hughes RN (eds) Reproductive Biology of Invertebrates. Vol. XI: Progress in Asexual Reproduction. Oxford \& Ibh Publishing Co Pvt Ltd pp. 141-158.

BOERO, F., BOUILLON, J. and PIRAINO, S. (2005). The role of Cnidaria in ecology and evolution. Ital. J. Zool. 72: 65-71.

CAMERON, R.A., TOSTESON, T.R. and HENSLEY, V. (1989). The control of sea urchin metamorphosis: Ionic effects. Develop Growth \& Differ 31: 589-594.

CARPIZO-ITUARTE, E. and HADFIELD, M.G. (1998). Stimulation of Metamorphosis in the Polychaete Hydroides elegans Haswell (Serpulidae). Biol. Bull. 194: 14-24.

CARLÀ, E.C., PAGliARA, P., PIRAINO, S., BOERO, F. and DINI, L. (2003). Morphological and ultrastructural analysis of Turritopsis nutricula during life cycle reversal. Tissue Cel/35: 213-222.

DE VITO, D., PIRAINO, S., SCHMICH, J., BOUILLON, J. and BOERO, F. (2006). Evidence of reverse development in Leptomedusae (Cnidaria, Hydrozoa): the case of Laodicea undulata (Forbes and Goodsir 1851). Mar. Biol. 149: 339-346.

FREY, J. (1968). Die Entwicklungsleistungen der Medusenknospen und Medusen von Podocoryne carnea M. Sars nach Isolation und Dissoziation. Wilhelm Roux's Archives 160: 428-464.
FRANK, U., LEITZ, T. and MÜLLER, W.A. (2001). The hydroid Hydractinia: a versatile, informative cnidarian representative. Bioessays 23: 1-9.

FREEMAN, G. (1993). Metamorphosis in the brachiopod Terebratalia: Evidence for a role of calcium channel function and the dissociation of shell formation from settlement. Biol. Bull. 184: 15-24.

GILI, J.M. and HUGHES, R.G. (1995). The ecology of marine benthic hydroids. Oceanogr. Mar. Biol. Ann. Rev. 33: 351-426.

HADZI, J. (1909). Rückgängig gemachte Entwicklung einer Scyphomeduse. Zool. Anz. 34: 7-9.

HERRMANN, K. (1995). Induction and regulation of metamorphosis in planktonic larvae: Phoronis milleri(Tentaculata) as archetype. Helgol. Wiss. Meeresunters. 49: 255-281.

KROIHER, M., WALTHER, M. and BERKING, S. (1992). Heat shock as inducer of metamorphosis in marine invertebrates. Roux's Arch. Dev. Biol. 201: 169-172.

KROIHER, M. and BERKING, S. (1999). On natural metamorphosis inducers of the cnidarians Hydractinia echinata (Hydrozoa) and Aurelia aurita (Scyphozoa). Helgol. Mar. Res. 53: 118-121.

LEITZ, T and MÜLLER, W.A. (1987). Evidence for the involvement of PI-signaling and diacylglycerol second messengers in the initiation of metamorphosis in the hydroid Hydractinia echinata Fleming. Dev. Biol. 121: 82-89.

LEITZ, T. and WAGNER, T. (1993). The marine bacterium Alteromonas espejiana induces metamorphosis of the hydroid Hydractinia echinata. Mar. Biol, (Berl) 115: 173-178.

LEITZ,T., MORAND, K. and MANN, M. (1994). Metamorphosin A, a novel peptide controlling development of the lower metazoan Hydractinia echinata. Dev. Biol. 163: 440-446.

LICHTNECKERT, R., MÜLLER, P., SCHMID, V. and REBER-MÜLLER, S. (2002). Evolutionary conservation of the chromatin modulator Polycombin the jellyfish Podocoryne carnea. Differentiation 70: 422-8.

MEIER, P., FINCH, A. and EVAN, G. (2000). Apoptosis in development. Nature 407:796-801.

MINELLI, A. (2003). The development of animal form: ontogeny, morphology and evolution. Cambridge University Press, pp. 1-323.

MÜLLER, H.C. (1913). Die Regeneration der Gonophore bei den Hydroiden Hydroiden und anschliessende biologische Beobachtungen I. Athecata. Arch. Entwicklungsmech Org. 37: 319-419.

MÜLLER, P., YANZE, N., SCHMID, V. and SPRING, J. (1999). The homeobox gene Otx of the jellyfish Podocoryne carnea: role of a head gene in striated muscle and evolution. Dev. Biol. 216: 582-94.

MÜLLER, M., SEIPEL, K., REBER-MÜLLER, S., STREITWOLF-ENGEL, R., STIERWALD, M., SPRING, J. and SCHMID, V. (2003). Evolutionary aspects of developmentally regulated helix-loop-helix-transcription factors in striated muscle of jellyfish. Dev. Biol. 255: 216-229.

MÜLLER, W.A. (1969). Auslösung der Metamorphose durch Bakterien bei den Larven von Hydractinia echinata. Zool Jb Anat 86: 84-95.

MÜLLER, W.A. and BUCHAL, G. (1973). Metamorphose-Induktion bei Planulalarven, II. Induktion durch monovalente Kationen: Die Bedeutung des Gibbs-DonnanVerhältnisses und der $\mathrm{Na}+/ \mathrm{K}_{+}-\mathrm{ATP}$ ase. Wilhelm Roux's Archives 173: 122135.

MÜLLER, W.A. (1973). Induction of metamorphosis by bacteria and ions in the planulae of Hydractinia echinata; An approach to the mode of action. Pub. Seto. Mar.,Biol. Lab. 20: 194-208.

MÜLLER, W.A. and LEITZ, T. (2002). Metamorphosis in the Cnidaria. Can. J. Zool. 80: 1755-1771.

PIRAINO, S., BOERO, F., AESCHBACH, B. and SCHMID, V. (1996). Reversing the life cycle: medusae transforming into polyps and cell transdifferentiation in Turritopsis nutricula (Cnidaria, Hydrozoa). Biol. Bull. 190: 302-312.

PIRAINO, S., DE VITO, D., SCHMICH, J., BOUILLON, J. and BOERO, F. (2004). Reverse development in Cnidaria. Can. J. Zool. 82: 1748-1754.

PLICKERT, G., SCHETTER, E., VERHEY-VAN-WIJK, N., SCHLOSSHERR, J., STEINBÜCHEL, M. and GAJEWSKI, M. (2003). The role of a-amidated neuropeptides in hydroid development - LWamides and metamorphosis in Hydractinia echinata. Int. J. Dev. Biol. 47: 439-450.

REISINGER, (1957). Zur Entwicklungsgeschichte und Entwicklungsmechanik von Craspedacusta (Hydrozoa, Limnotrachylina). Z. Morph. Oekol. Tiere 45: 656- 


\section{J. Schmich et al.}

698.

RICCI, C. (1998). Anhydrobiotic capabilities of bdelloid rotifers. Hydrobiologia387/ 388: 321-326.

SCHMID, V. and TARDENT, P. (1969). Zur Gametogenese von Podocoryne carnea M. Sars. Revue Suisse Zool. 76 (4)(55): 1071-1078.

SCHMID, V. (1972). Untersuchungen über Dedifferenzierungsvorgänge bei Medusenknospen und Medusen von Podocoryne carnea M. Sars. Wilhelm Roux's Archives 169: 281-307.

SCHMID, V. (1979). The use of anthomedusae in establishing an in vitroregeneration system. Ann. Soc. Fr. Biol. Dev. 35-38.

SCHMID, V., STIDWILL, R. BALLY, A. MARCUM B. and TARDENT, P. (1981). Heat dissociation and maceration of marine Cnidaria. Wilhelm Roux's Archives 190 3: $143-149$.

SCHMID, V. (1992). Transdifferentiation in medusae. International Rev. Cyt. 142: 213-261.

SCHMID, V. and REBER-MÜLLER, S. (1995). Transdifferentiation of isolated striated muscle of jellyfish in vitro: the initiation process. Semin. Cell. Biol. 6(3): 109-116.

SCHMICH, J., TREPEL, S. and LEITZ, T. (1998a). The role of GLWamides in metamorphosis of Hydractinia echinata. Dev. Genes Evol. 208: 267-273.

SCHMICH, J., RUDOLF, R., TREPEL, S. and LEITZ, T. (1998b). Immunohistochemical studies of GLWamides in Cnidaria. Cell Tissue Res. 294: 169-177.

SCHUCHERT, P. (2004). Revision of the European athecate hydroids and their medusae (Hydrozoa, Cnidaria). Families Oceanidae and Pachycordylidae. Rev Suisse Zool. 111: 315-369.

SEIPEL, K., YANZE, N. and SCHMID, V. (2004a). The germ line and somatic stem cell gene Cniwinn the jellyfish Podocoryne carnea. Int. J. Dev. Biol. 48: 1-7. http:/ /dx.doi.org/10.1387/ijdb.15005568

SEIPEL, K., YANZE, N. and SCHMID, V. (2004b). Developmental and evolutionary aspects of the basic helix-loop-helix transcription factors Atonal-like 1 and Achaete-Scute homolog 2 in the jellyfish. Dev. Biol. 269: 331-345.

SEIPEL, K., YANZE, N., MÜLLER, P., STREITWOLF, R. and SCHMID, V. (2004c). Basic leucine zipper transcription factors $C / E B P$ and MafL in the hydrozoan jellyfish Podocoryne carnea. Dev. Dyn. 230: 392-402.

SEIPEL, K., EBERHARDT, M., MÜLLER, P., PESCIA, E., YANZE, N. and SCHMID, V. (2004d). Homologs of vascular endothelial growth factor and receptor, VEGF and VEGFR, in the jellyfish Podocoryne carnea. Dev. Dyn. 231: 303-312.

SEIPEL, K. and SCHMID, V. (2005). Evolution of striated muscle: Jellyfish and the origin of triploblasty. Dev. Biol. 282: 14-26.

SEIPP, S., SCHMICH, J. and LEITZ, T. (2001). Apoptosis - a death inducing mechanism tightly linked with morphogenesis in Hydractina echinata(Cnidaria, Hydrozoa). Development 128: 4891-4898.
SEIPP, S., SCHETTER, E., SCHMICH, J., PLICKERT, G. and LEITZ, T. (2002). Apoptotic elimination of neuronal cells during metamorphosis of Hydractinia echinata. Zoology 105 Supplement IV, 14.

SEIPP, S., WITTIG, K., STIENING, B., BÖTTGER, A. and LEITZ, T. (2006). Metamorphosis of Hydractinia echinata(Cnidaria) is caspase-dependent. Int. J. Dev. Biol. 50: 63-70.

SOKAL, R. R. AND ROHLF, F. J. (1994). Biometry: the principles and practice of statistics in biological research. 3rd edition. New York: Freeman.

SPRING, J., YANZE, N., MIDDEL, A.M., STIERWALD, M., GRÖGER, H. and SCHMID, V. (2000). The mesoderm specification factor Twistin the life cycle of jellyfish. Dev. Biol. 228: 363-75.

SPRING, J., YANZE, N., JÖSCH, C., MIDDEL, A.M., WINNINGER, B. and SCHMID, V. (2002). Conservation of Brachyury, Mef2 and Snail in the myogenic lineage of jellyfish: A connection to the mesoderm of Bilateria. Dev. Biol. 244: 372-84.

STIERWALD, M., YANZE, N., BAMERT, R., KAMMERMEIER, L. and SCHMID, V. (2004). The Sine oculis/Six class family of homeobox genes in jellyfish with and without eyes: development and eye regeneration. Dev. Biol. 274:70-81.

TODD, C.D., BENTLEY, M.G. and HAVENHAND, J.N. (1991). Larval metamorphosis of the opisthobranch mollusc Adalaria proxima (gastropoda: nudibranchia): The effects of choline and elevated potassium ion concentration. J. Mar. Biol. Ass. 71: 53-72.

TORRAS, R., YANZE, N., SCHMID, V. and GONZALEZ-CRESPO, S. (2004). nanos expression at the embryonic posterior pole and the medusa phase in the hydrozoan Podocoryne carnea. Evol. Dev. 6: 6362-371.

VALENTINI S. (2006). Analysis of apoptosis during reverse development in Turritopsis dohrnii and in the life cycle of Eleutheria dichotoma (Cnidaria, Hydrozoa). Diploma thesis, University of Kaiserslautern and University of Lecce, pp. 1-87.

WOMERSLEY, C.Z., WHARTON, D.A. and, HIGA, L.M. (1998). Survival biology. In: Perry RN, Wright DJ, (eds) The physiology and biochemistry of free-living and plant-parasitic nematodes. Oxon: CABI Publishing, pp 271-302.

WOOLLACOTT, R.M. and HADFIELD, M.G. (1996). Induction of metamorphosis in larvae of a sponge. Invertebr. Biol. 115: 257-262.

YANZE, N., SPRING, J., SCHMIDLI, C. and SCHMID, V. (2001). Conservation of Hox/ParaHox-related genes in the early development of a cnidarian. Dev. Biol. 236: 89-98.

Received: 30th January 2006 Reviewed by Referees: 17th March 2006 Modified by Authors and Accepted for Publication: 23rd August 2006 Published Online: 22nd November 2006 